\title{
Recognition of how to Computational Simulate the Formation Processes of Biological Phenomena in Algorithmic Architecture
}

\author{
Yashar Gharachamani Asl ${ }^{1}$, Mohammad Baharvand ${ }^{1^{*}}$, Sahar Toofan ${ }^{2}$
}

\begin{abstract}
There is a long history behind the idea of contemplating the natural world and paying attention to the ways biological phenomena develop and grow rather than trying to merely imitate them in a superficial manner. However, until recently the scientific and technological capabilities had not advanced enough to implement this concept. This was perhaps the result of a superficial selection of complex and ungraspable subjects that could not be implemented due to a lack of scientific knowledge and technical capabilities. However, nowadays it is possible to have a deeper understanding of the principles of form creation thanks to the technical and scientific developments in the past few decades. The patterning and imitation processes go beyond the formal scope to encompass the entire knowledge of how biological components are formed, providing valuable area for pattern generation. Such a new method of imitating nature can be found in algorithmic design, which is to make use of computation as the main part of computer activities through algorithms and codes and programs, like a genome in nature. The main goal of this research is to provide a clear framework and a systematic approach to the role of computational generative systems in the form generation process. For this purpose, the present study uses a descriptive-analytical method based on library research, to study and categorize and describe characteristics, mechanism of the computational systems used in form creation and Compare them. It concludes that computational systems inspired by biological principles can play an important role in the process of computational form generation in architecture.
\end{abstract}

Keywords: Algorithmic Architecture, generative systems, biological systems, growth pattern, computation.

\section{Introduction}

In the last century, many computational approaches and methods have been introduced, such as cellular automation and L-systems that are inspired by the process of biological phenomena formation; Therefor, the methods of creating the architectural form have been more apparent and shape-based. If deepened, it remains only in the form of a theory and does not go beyond the bounds. Perhaps the reason for this is the superficial selection of complicated and uncompromising issues in terms of weakness in the field of science or the lack of technical means for implementation (Taraz, 2012).

According to the technical and scientific developments of the recent decades, scientific disciplines have increased their participation in architecture. Biology is one of these outstanding disciplines. Understanding the scientific scope and transitional movement from the field of biological knowledge to architecture can open the way for

\footnotetext{
| 1Department of Architecture, Isfahan (Khorasgan) Branch, Islamic Azad University, Isfahan, Iran

${ }^{2}$ Department of Architecture, Tabriz Branch, Islamic Azad University, Tabriz, Iran

*corresponding author: Dr. Mohammad Baharvand; Assistant Professor, Department of Architecture, Isfahan (Khorasgan) Branch, Islamic Azad University, Isfahan, Iran.
} 
understanding the deep layers, as well as their formation and growth, rather than imitating them at the initial levels of the formal and mechanical forms of organisms (Caboli and Khandan, 2015). Christopher Alexander says that without understanding the patterns, one could not be successful through application of the possibilities while come across with a wide range of distinct conditions (Qaruni Esfahani, 2015).

On the other hand, the study and programming of these patterns in the digital instrument has made it possible to produce patterns similar to those in nature at the field of formation and enter them into design stages. Recently it is possible to summarize the most complicated natural subjects as algorithms and to transform the complexity of the space into computational complexity (Khabazi, 2016), and the modeling of the biological processes can be coded and programmed in the direction of computing, and form production.

In general, the combination of biological knowledge with algorithmic architecture will lead to the production of new scientific design issues and the path to research will open up the vision of creativity and innovation to form production. These visions and new subject-matters seem to appear in the algorithmic channels, and they gain more production facilities (Khabazi, 2016). However, the use of this type of knowledge in the contemporary architectural paradigm and the scientific-biological view of nature has opened up a long way to research for designers, and the explanation of the features of this type of architecture in the middle of the way, while the published texts of the theory are limited. Because this is a constant flow of change, so that some new features can be studied and written each day for this flow of architecture.

\subsection{Research Background}

The computing systems have been around for over half a century, affecting the field of architecture and the production process of the form. Such systems were initially began with theories such as Artificial Neural Networks, Cellular Automation, Genetic Algorithms, L-Systems Although the first step in the 1940s was removed, these theories developed exponentially in the 1960s and 1970s with the advancement of technology. In the last decade of the twentieth century, these principles established a major part of the research on Form Generation Techniques and Tools based on theories of automated cellular machines, genetic algorithms, and L- Systems. These techniques were developed by designers and scientists such as John Fraser, Makoto Watanabe, Michael Rosenman and John Gero, and Martin Hemberg, Una May Orielly and Peter Testa were promoted.

In the first two decades of the $21^{\text {st }}$ century, a new generation of pioneering architects, such as Michael Hensel, Achem Menges and Michael Weinstock of the London Architectural Society, founded the Emerging Technologies and Principles Group, Promote a modern architectural approach that defines a reciprocal relationship between new biological concepts such as emergence and self-organization and the latest design, manufacturing and producing technologies that, along with the other researchers such as Neri Oxman in Materials Ecology, Jenny Sabin and Peter Lloyd Jones, Andrew kudless 
in Materials System and Chris Bosse are shaping the boundaries of a new paradigm in architecture.

\subsection{Theoretical Framework}

In general, the research background and theoretical foundations can be considered in three parts of theories, methods, and producing process. The classification is initially began with competing theories based on biological processes, according to the hierarchy of their occurrence, then continued with the introduction of modern computational methods based on biological principles and ultimately are terminated with the application of such ideas and methods in the formulation and production of the computational form.

Table 1. Computational systems based on biological principles

\begin{tabular}{|c|c|c|c|c|}
\hline \multicolumn{2}{|c|}{ Framework } & Year & Description & References \\
\hline \multirow{4}{*}{ 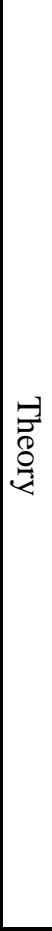 } & $\begin{array}{l}\text { cellular } \\
\text { automato } \\
\mathrm{n}\end{array}$ & 1940 & $\begin{array}{l}\text { A cellular automaton, a mathematical and } \\
\text { computational system, developed by Neumann John } \\
\text { Von, Stanislav Ulam and Nils Barricelli }\end{array}$ & $\begin{array}{l}\text { (Wolfram, } \\
\text { 1983) } \\
\text { (Frenay, } \\
\text { 2008) }\end{array}$ \\
\hline & $\begin{array}{l}\text { Genetic } \\
\text { algorithm } \\
\text { and } \\
\text { evolution } \\
\text { ary } \\
\text { computin } \\
\text { g }\end{array}$ & 1960 & $\begin{array}{l}\text { John Holland, for the first time, proposed the idea of } \\
\text { genetic algorithm and evolutionary computing. } \\
\text { Genetic algorithm is an empirical method of natural } \\
\text { evolution, comparable to concepts such as pair, } \\
\text { mating, chromosomal subsystem, genetic mutation, } \\
\text { adaptation, and natural selection }\end{array}$ & $\begin{array}{l}\text { (Holland, } \\
\text { 1992) } \\
\text { (Winston, } \\
\text { 1992) } \\
\text { (Steadman, } \\
\text { 2008) }\end{array}$ \\
\hline & L-system & 1968 & $\begin{array}{l}\text { An electronic system (Lindenmeyer system) was } \\
\text { proposed to describe the growth of organisms. This } \\
\text { system is a hierarchical algorithm retrieved by a } \\
\text { botanist named Aristide Lindenmeyer in } 1968 \text {. }\end{array}$ & $\begin{array}{l}\text { (Steadman, } \\
2008 \\
\text { (Prusinkie } \\
\text { wicz, } \\
1986 \text { ) }\end{array}$ \\
\hline & $\begin{array}{l}\text { Fractal } \\
\text { Theory }\end{array}$ & 1975 & $\begin{array}{l}\text { In 1975, Fractal Theory, which is based on the work } \\
\text { of mathematicians such as Felix Hausdorff, was first } \\
\text { called by Benoit Mandelbrot. The fractal is defined as: } \\
\text { "Any irregular form with a variety of shapes that each } \\
\text { section is selected from when it is zoomed in or zoom } \\
\text { out in appearance with a larger or smaller portion" }\end{array}$ & $\begin{array}{l}\text { (Bovill, } \\
\text { 1996) }\end{array}$ \\
\hline $\begin{array}{l}\frac{3}{0} \\
\frac{1}{0} \\
\frac{0}{0} \\
0 \\
0 \\
00\end{array}$ & $\begin{array}{l}\text { Evolution } \\
\text { ary } \\
\text { Archirect } \\
\text { ure }\end{array}$ & 1995 & $\begin{array}{l}\text { The idea of evolutionary architecture dates back to } \\
1969 \text { in the John Frazer Encyclopedia as one of the } \\
\text { decoders of the process of generating computational } \\
\text { forms. The evolutionary architecture has been } \\
\text { developed to imitate the symbiotic behavior and } \\
\text { metabolic balance of the natural environment }\end{array}$ & $\begin{array}{l}\text { (Steadman, } \\
\text { 2008) } \\
\text { (Frazer, } \\
\text { 2002) }\end{array}$ \\
\hline
\end{tabular}




\begin{tabular}{|c|c|c|c|c|}
\hline & $\begin{array}{l}\text { Methods } \\
\text { for } \\
\text { Evolution } \\
\text { ary } \\
\text { Archirect } \\
\text { ure }\end{array}$ & 1996 & $\begin{array}{l}\text { In the 1990s, Michael Rosenmann and John Gero } \\
\text { worked on evolutionary architectural techniques at the } \\
\text { University of Sydney. Their research focuses on } \\
\text { evolutionary design through the production of } \\
\text { complex genetic structures. They obtained different } \\
\text { approaches, such as the complex structure of evolving } \\
\text { genes, from a certain population of design solutions, } \\
\text { using a hierarchical growth approach }\end{array}$ & $\begin{array}{l}\text { (Gero, } \\
\text { 1999) } \\
\text { Steadman, } \\
\text { 2008) } \\
\text { (Rosenman } \\
\text { and Gero, } \\
\text { 1999) }\end{array}$ \\
\hline \multirow{3}{*}{ 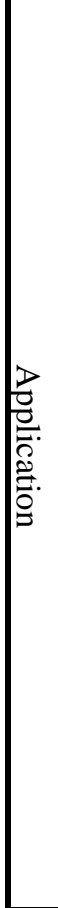 } & $\begin{array}{c}\text { Emergent } \\
\text { Technolo } \\
\text { gies and } \\
\text { design }\end{array}$ & $\begin{array}{l}2004 \\
\text { up to } \\
\text { now }\end{array}$ & $\begin{array}{l}\text { Michael Hensel, Achim Manges and Michael } \\
\text { Weinstock, co-founders and administrators of the } \\
\text { Emerging Technologies and Design Principles at the } \\
\text { London Architectural Association, have been } \\
\text { introducing new ways of visualizing, designing, and } \\
\text { manufacturing in architecture since 2004. They have } \\
\text { explored concepts such as emergence, morphogenesis, } \\
\text { morpho-ecology }\end{array}$ & $\begin{array}{l}\text { (Hensel } \\
\text { and } \\
\text { Menges, } \\
\text { 2008) } \\
\text { (Hensel, } \\
\text { Menges } \\
\text {,Weinstock } \\
\text {,2013) }\end{array}$ \\
\hline & $\begin{array}{l}\text { Optimaza } \\
\text { tion } \\
\text { technique }\end{array}$ & $\begin{array}{l}2006 \\
\text { up to } \\
\text { now }\end{array}$ & $\begin{array}{l}\text { The German architect, Chris Bosse, created the space } \\
\text { in architecture since } 2006 \text { using computational } \\
\text { methods for studying organic structures. He uses the } \\
\text { technique of optimizing the form of organism instead } \\
\text { of direct design of the form, using a similar process to } \\
\text { that of natural organisms }\end{array}$ & $\begin{array}{l}\text { (bosse, } \\
2019 \text { ) } \\
\text { (Iwamoto, } \\
2009 \text { ) }\end{array}$ \\
\hline & $\begin{array}{c}\text { Lab } \\
\text { Studio }\end{array}$ & $\begin{array}{l}2008 \\
\text { up to } \\
\text { now }\end{array}$ & $\begin{array}{l}\text { The collaboration between Jenny Sabin and Peter } \\
\text { Lloyd Jones, respectively, as an architect and } \\
\text { molecular biologist, has been developing a } \\
\text { collaborative relationship between cell biology and } \\
\text { architecture as the studio lab (Sabin, 2019) with a new } \\
\text { research on a kind of design between knowledge It is } \\
\text { on a common ground between architecture, science } \\
\text { and technology (Chernyakova, 2016) }\end{array}$ & $\begin{array}{l}\text { (Sabin, } \\
\text { 2019) } \\
\text { (Chernyak } \\
\text { ova, 2016) }\end{array}$ \\
\hline
\end{tabular}

\section{Methodology}

The present study uses descriptive-analytic research methodology proceeding by studying and collecting necessary documentation from various library resources including articles, dissertations, books and scientific journals of foreign and domestic universities, first with categorizing generative systems into six parts, Including algorithmic, parametric, Linden Mayer systems (L-systems), automated cellular, fractal, and shape grammars, describes analytically the characteristics and mechanisms of the functions of various generative systems as well as the governing relationships among their components in the form of tables and diagrams and illustrations, then a comprehensive comparison between the various types of systems might be occurred. This is aimed at providing a specific framework and a systematic approach to the role of computer systems inspired by biological principles in the process of producing an architectural form. 


\section{Results and discussion}

\subsection{Generative design}

Generative design is a morphogenesis process that uses algorithms composed of nonlinear systems such as genetic algorithms to produce endless and unrepeatable unique results of the code idea, as is the nature of this., Is done. (Soddu and Colabella, 1995) (Fig.1).

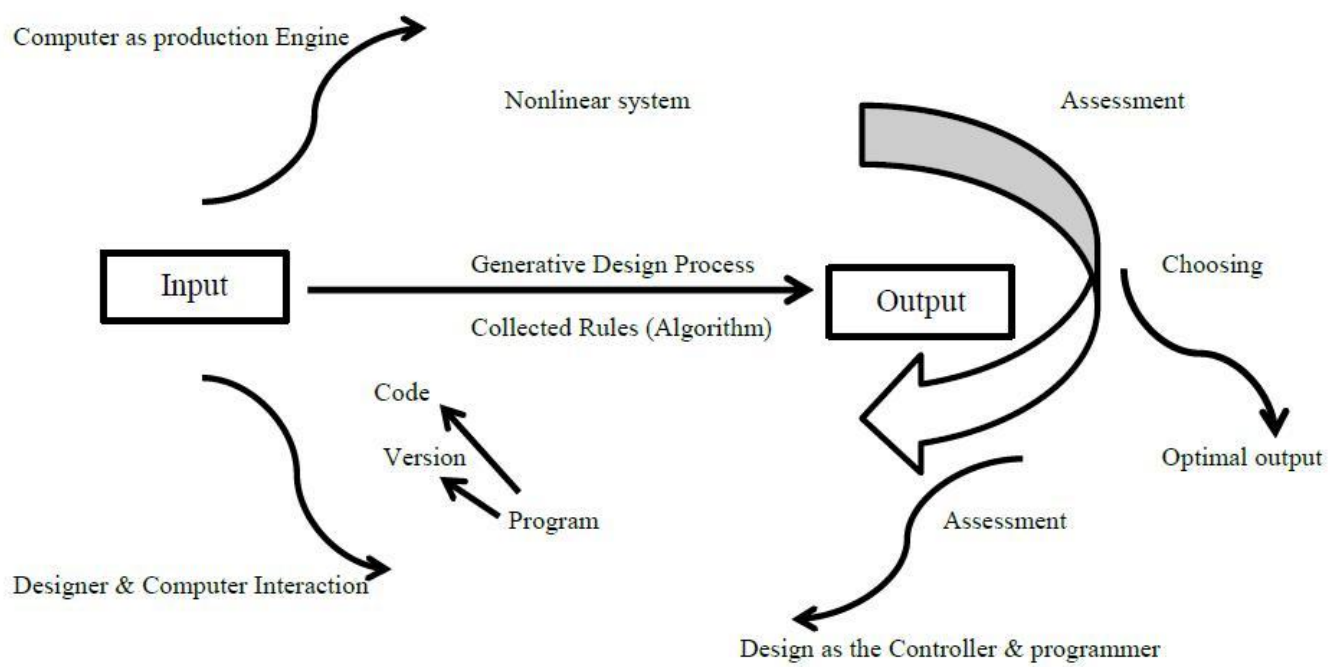

Fig.1. Generative Design Approach

As with nature, with encoding, the design process takes place instead of the product itself, requiring computing features of the rules and form production principles, exploration of options, and design variables. (Gursel, 2012) (Figure 2) 


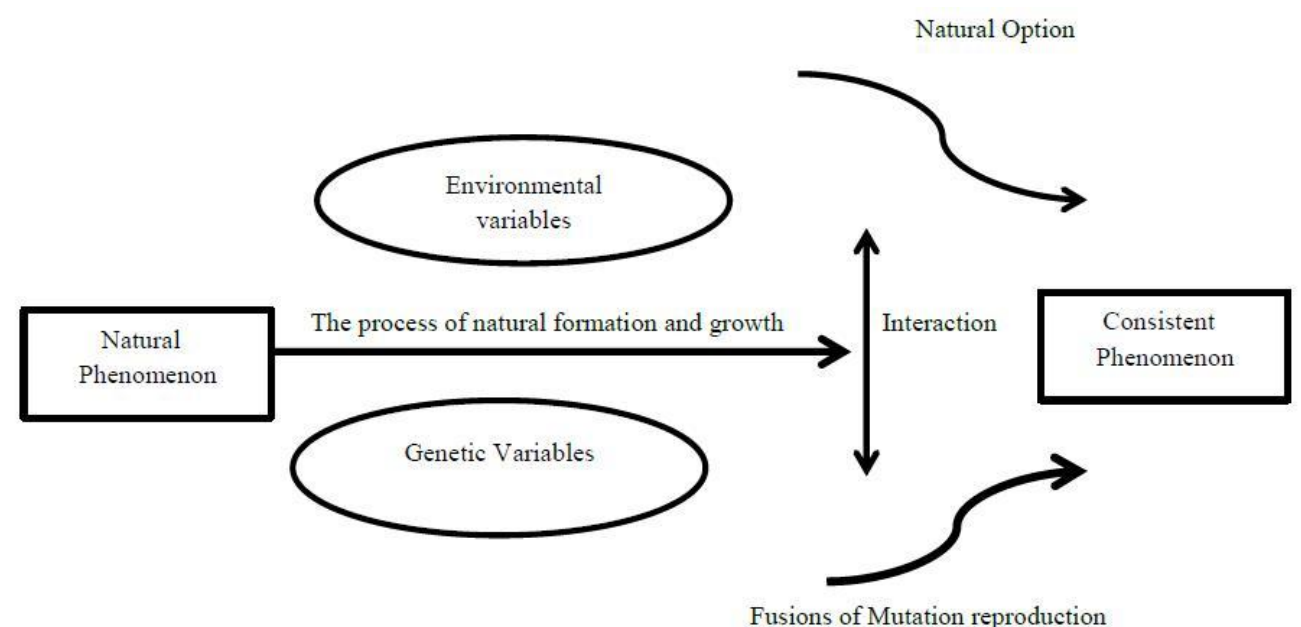

Fig.2. Genetic Algorithm Natural Approach

\subsection{Generative Systems}

Generative systems (Figure 3) are a system that considers the complex nature of the living entity as a default, and its rules, as a natural occurrence, describe the methods in which complex natural systems of evolution, Self-organization and growth. It employs extraction and becomes an architectural form. (Hensel, Menges, Weinstock, 2010).

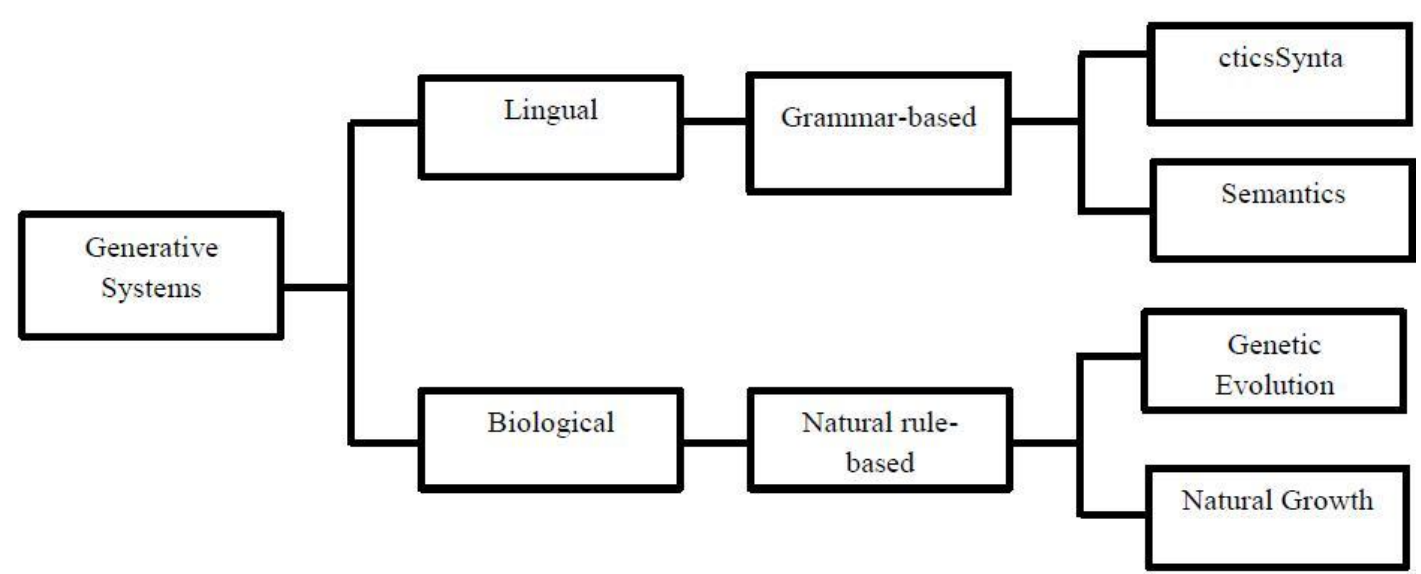

Fig.3. Categories of Generative Design Systems

\subsection{Generative Models}

Generative models (Fig. 4), like evolutionary form-generation techniques, based on the natural selection of generations, are "the design of complex mechanisms and their interaction with the emergence of forms derived from laws, relationships and principles 
of production, and it works (Oxman, 2006).

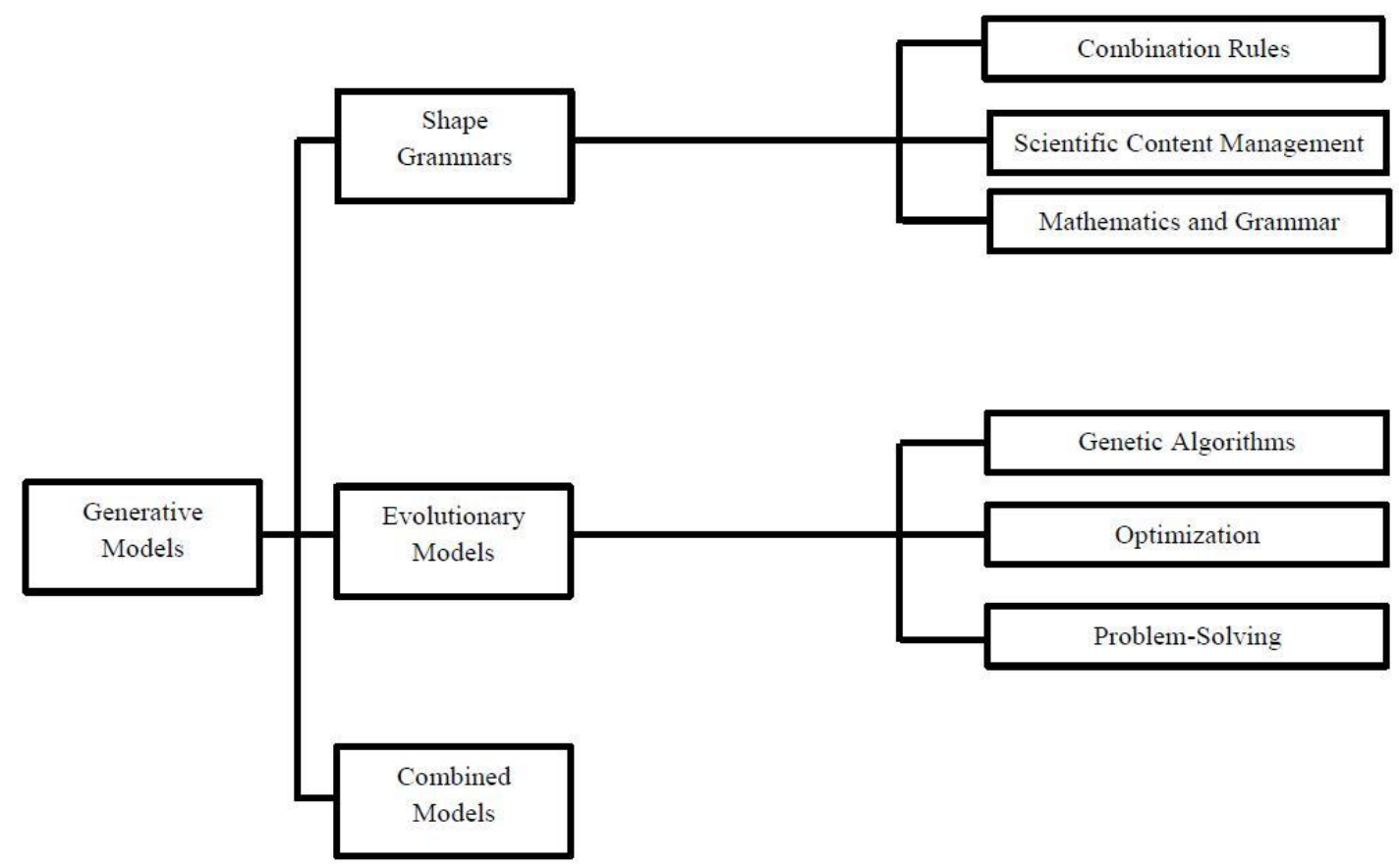

Fig.4. Categories of Generative Models

\subsection{Generative System Approaches}

Generative systems approaches (Fig. 5) have an algorithmic basis. By changing the variables in them, a new solution is created; therefor, a variety of outputs which are measured and evaluated that can be produced in order to achieve the desired option. 


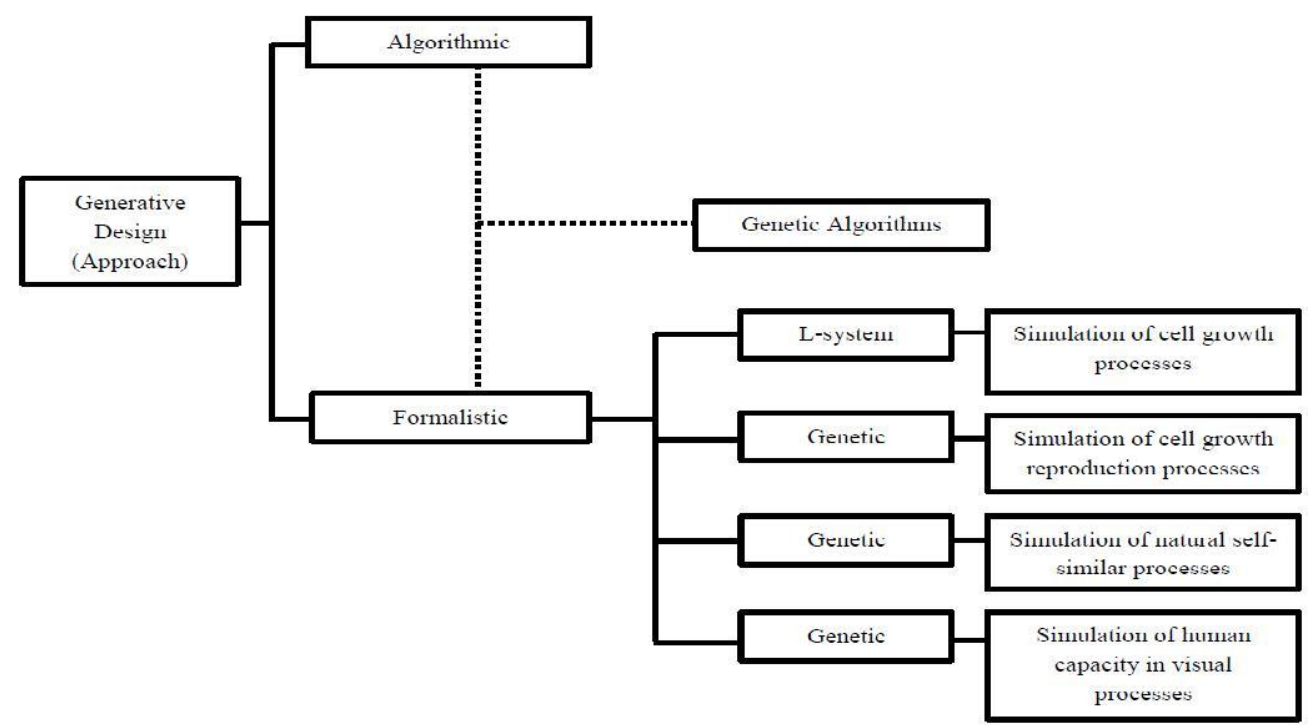

Fig.5-Generative Systems Approaches

\subsubsection{Algorithmic Systems}

Algorithmic systems are the main components of all generative systems. Algorithms categorize a set of instructions in different structures or rules. Such a process helps designers break down the text, understand the relationships, and devise ways to judge the results. (EI-Khaldi, 2007)

\subsubsection{Parametric Systems}

Parametric systems are a specific instance of algorithmic systems. The fact is that any system that can connect the elements to one another is a parametric system (Figure 6).

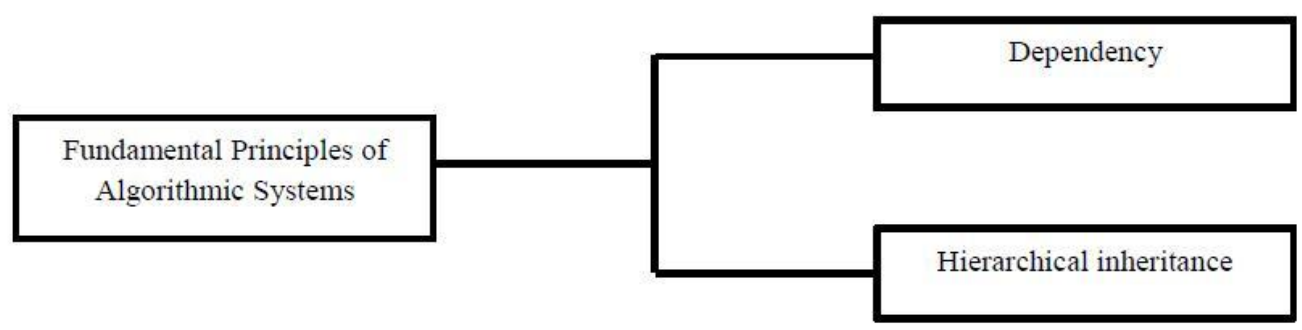

Fig.6. Concepts of Algorithmic Systems 
These systems allow the publication of values in common sets of parameters among the elements of a family or different families (Figure 7).

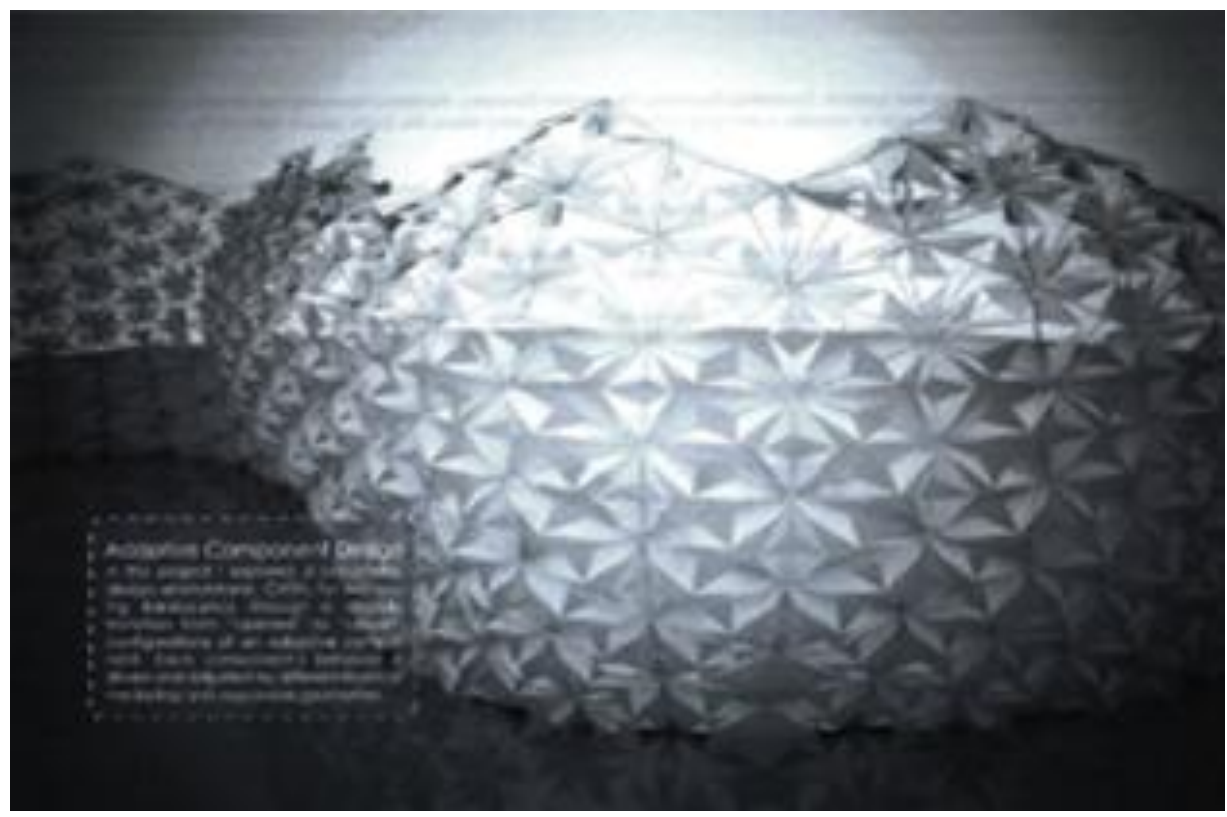

Fig. 7. Experiment: Parametric Skin Component by Using Parametric Systems(Elkhaldi, 2007)

\subsubsection{Formalisms}

Formalisms are a rule-based system that is defined as formalism, which is designed to simulate a very natural and biological phenomenon, in contrast to the presentation of an operational plan (table 2; Elkhaldi, 2007).

Table 2. Patterns of formalism systems

\begin{tabular}{|c|c|c|}
\hline 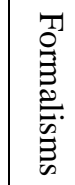 & Pattern & Shape \\
\hline
\end{tabular}




\begin{tabular}{|c|c|c|c|}
\hline $\begin{array}{l}5 \\
\vdots \\
0 \\
0 \\
0 \\
0 \\
3\end{array}$ & $\begin{array}{l}\text { Which are used } \\
\text { to simulate the } \\
\text { process of } \\
\text { plant growth }\end{array}$ & $\begin{array}{l}\text { Fig.8- Example showing L- } \\
\text { system formalism and } \\
\text { generated geometric } \\
\text { interpretation of the tree } \\
\text { growth }\end{array}$ & 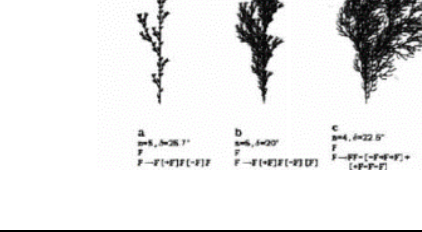 \\
\hline 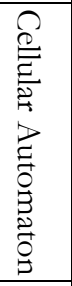 & $\begin{array}{c}\text { An auto- } \\
\text { cellular system } \\
\text { was created to } \\
\text { simulate } \\
\text { reproduction } \\
\text { and cell } \\
\text { proliferation. }\end{array}$ & $\begin{array}{c}\text { Fig.9- Rule } 30 \text { cellular } \\
\text { automaton }\end{array}$ & 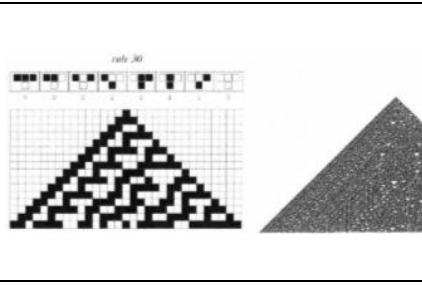 \\
\hline $\begin{array}{l}\text { Ty } \\
\stackrel{\vec{D}}{\overparen{D}} \\
\stackrel{\vec{D}}{ \pm}\end{array}$ & $\begin{array}{l}\text { The fractal } \\
\text { system is used } \\
\text { to simulate } \\
\text { self-similarity } \\
\text { in nature }\end{array}$ & Fig.10- Durer Pentagon & \\
\hline 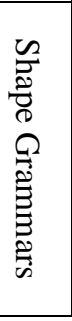 & $\begin{array}{c}\text { Oriented } \\
\text { shapes } \\
\text { grammars were } \\
\text { created to } \\
\text { simulate the } \\
\text { human ability } \\
\text { to visualize or } \\
\text { realization }\end{array}$ & $\begin{array}{l}\text { Fig.11- Left side is the rule, } \\
\text { right side are two possible } \\
\text { results }\end{array}$ & \\
\hline
\end{tabular}

\subsubsection{L-Systems}

L-systems can categorize different behaviors in a discrete unit of several letters and rules. The user only needs to provide rules and a basic discipline. Then, the string is broken and rewritten, and will be interconnected based on a certain number of generations.

\subsubsection{Cellular Automation Systems}

Automated cell systems can run automatically in a fixed number of times, or gradually, as long as the overall condition is achieved. In architecture, cellular automation is primarily modeled as generating systems for model generation (Figure 12) . 


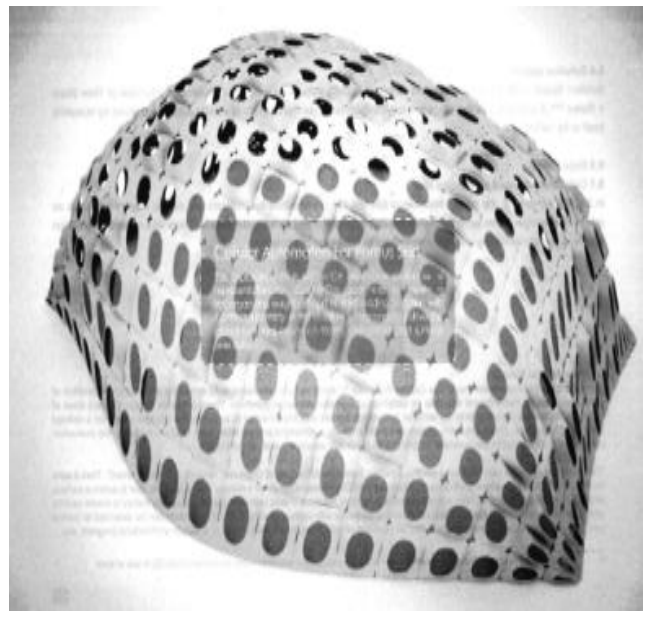

Fig.12. Experiment: Porous Skin Design by Using Cellular Automata Systems (Elkhaldi, 2007)

\subsubsection{Fractal Systems}

Fractal systems can be algorithmically similar to the production of objects with their components through the return 43. This system, based on recursive mathematical models, first breaks the elements and then replaces them with new elements (EI-Khaldi, 2007).

\subsubsection{Shape Grammars}

Graphic grammars are designed to perform visual computing processes in design. They act through recognition through the ability of man to see. Designers can detect and enforce a law wherever it is originally defined in a design (Table 3; EI-Khaldi, 2007).

Table 3. Characteristics of generative systems

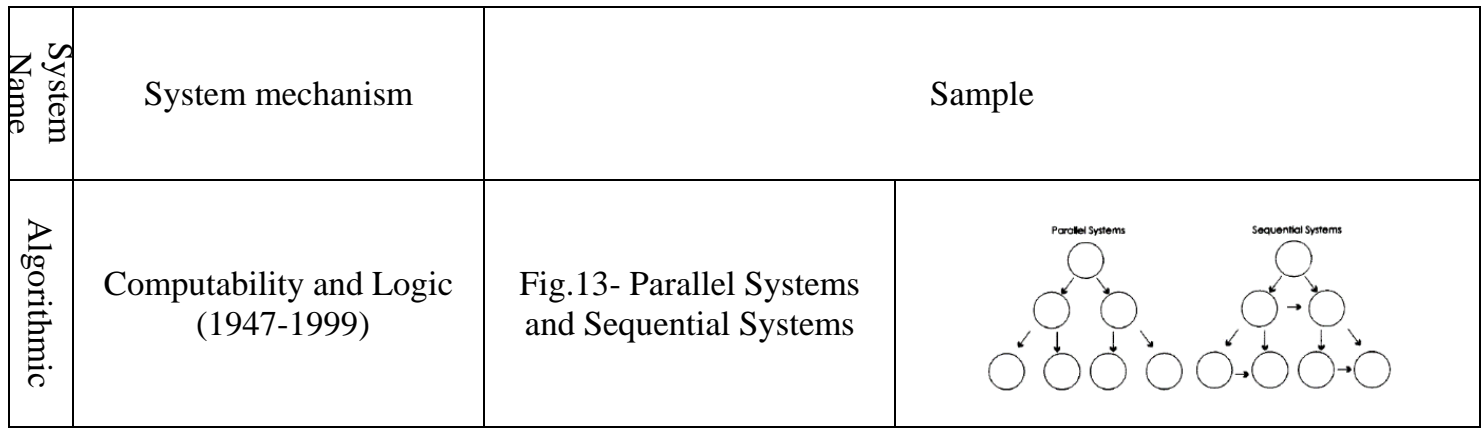




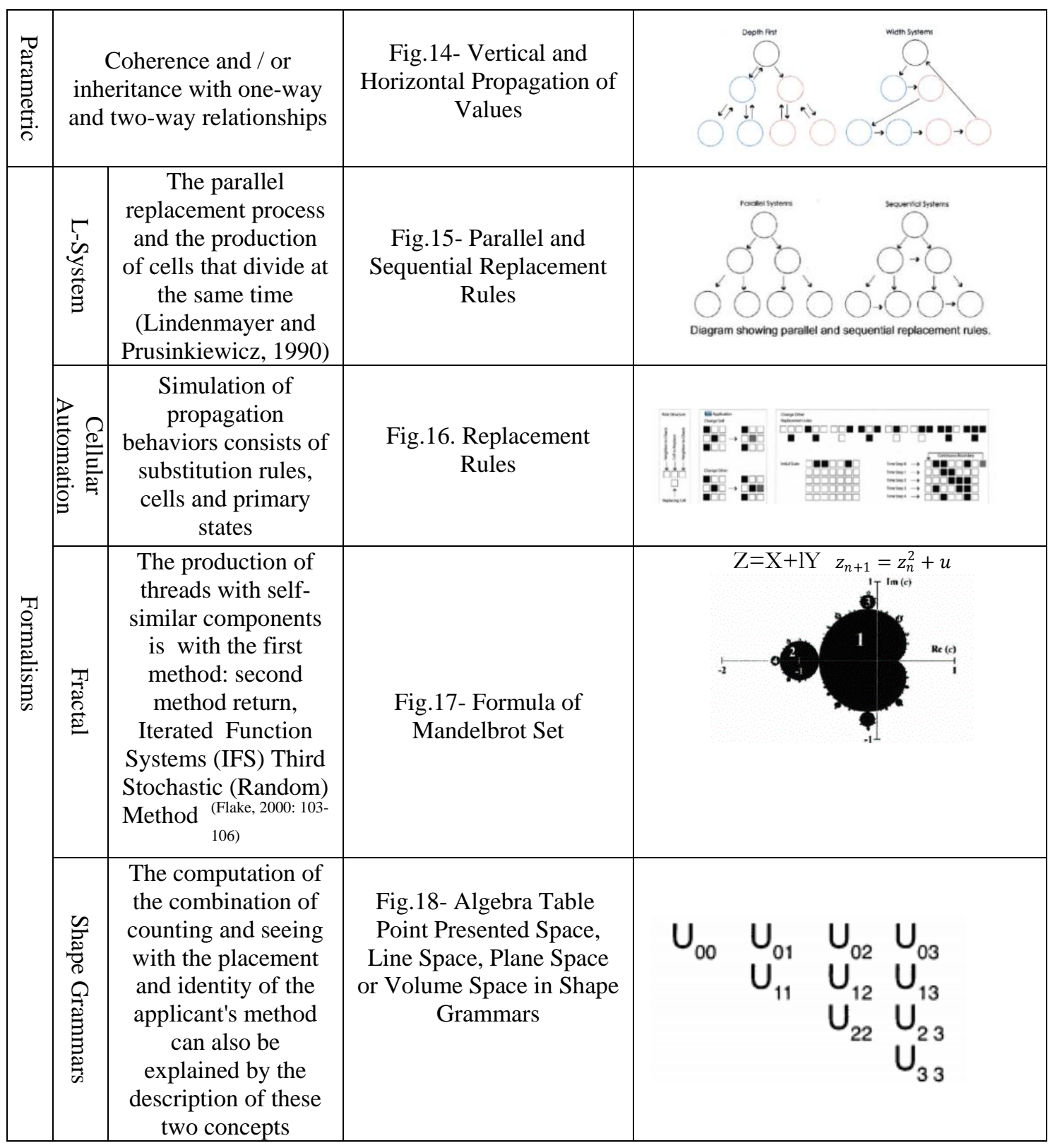

\subsection{Generative Systems Comparison}

Algorithmic systems are the basic components of all generative systems. They do not impose a particular structure or relationship or unit and field. Instead, they provide only one environmental place for executive instructions. In fact, they do not follow a particular structure. Parametric systems are a special mode of algorithmic system. The fact is that any system that can connect the elements to one another is a parametric system. These systems are hierarchical-algorithmic systems controlled by one- 
way relationships and permitting the emission of values in common sets of parameters among the elements of a family or different families. They are limited to relationships.

L-Systems are more specific than Algorithmic Systems, which, like all, rely on rules and units. The rules are not limited to a one-to-one replacement process. But at the same time apply to all the letters that represent the production of the cells in which the divisions occur simultaneously. In such a way that behaviors are grouped in a few letters and rules, and a tree-like network of alphabets is created, the generic set of which is called a solution. In terms of programming, it's easy to run these systems because of discrete units. The user only needs to provide rules and a basic discipline. Then, the string is broken and rewritten, and will be interconnected based on a certain number of generations. But the LS system has at least some flexibility. Its symbols are limited to a type of meaning.

If cellular automation systems provide a richer environment, its symbols are not limited to one kind of meaning. A symbol in a cell automaton can be referred to as a color with its variations (black, white, etc.) or size (with different numbers), location (relative to many axes), etc., and even different objects. This system with simple structure can exhibit complex and unexpected behaviors. The cellular automaton simulates the propagation behaviors by applying the rules of simultaneous replacement of the cell fragments (neighbors). Automated cellular rules can be automatically executed in a fixed number of times, repeatedly or gradually until a general condition is reached.

The two previous systems maintain their smallest units and replace the rules, letters, or cells without breaking them into lowercase letters. Despite of the fact, that the concept of "smallest unit" is not applicable in fractal systems. Due to their hierarchical in nature based on recursive mathematical models. Fractal algorithms first break the elements recursively, then replace them with new elements, and break up units into smaller units, and then apply the replacement rules until they meet a stop condition.

All previous systems identify units individually (with specific boundaries) assuming that they retain their identity during the computational process in a definite manner. If in form-based grammars, units are also fixed by definitions and they are also flexible. Of course, grammatical forms, like all other formalisms, rely on rules and units. However, units are defined only by the topology and not by size and location (position). Designers can implement a rule wherever they identify the original form in a particular design. In general, in a form-forming process, all generative systems with their unique features can be interconnected in an interactive system (Figure 19). 


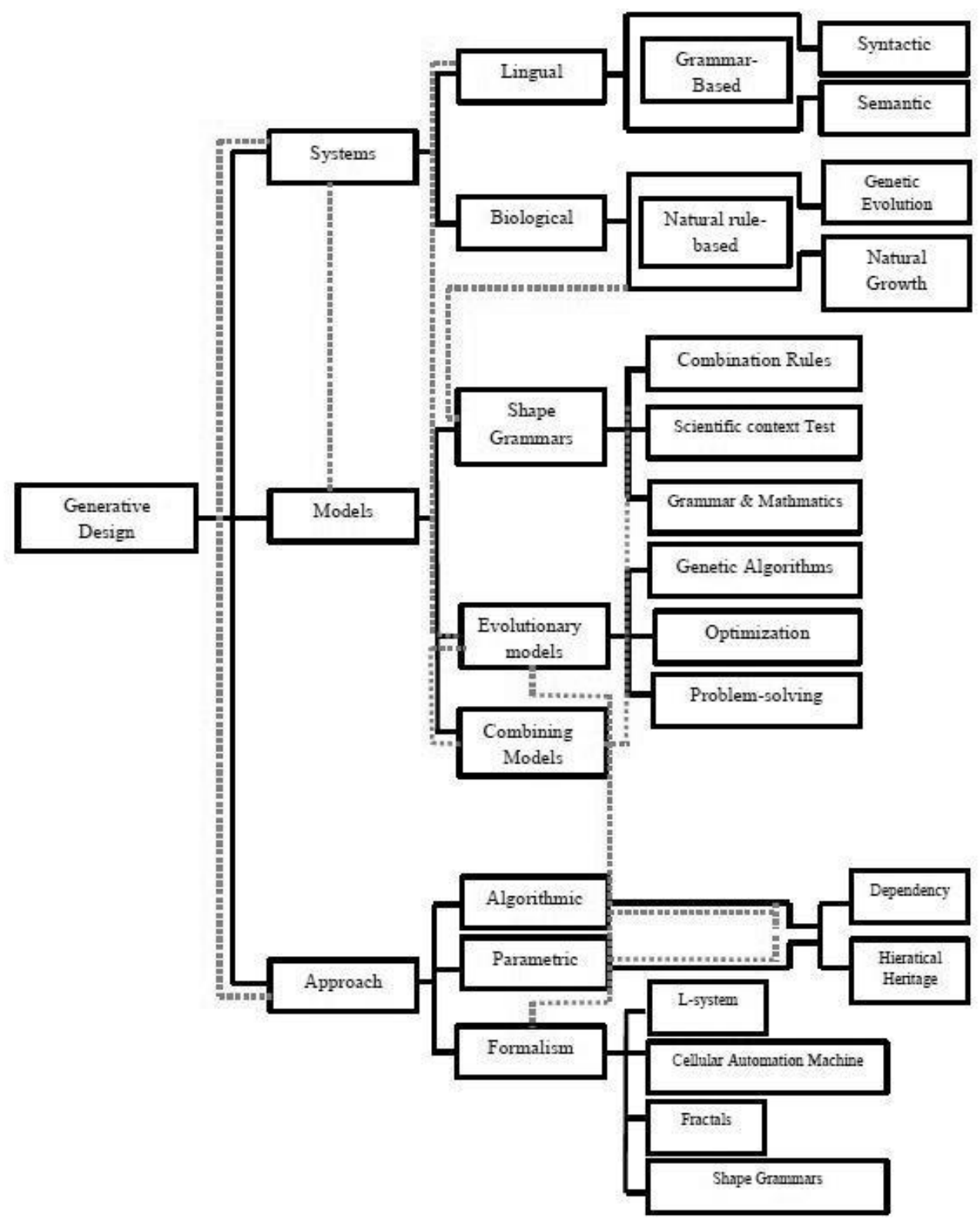

Fig.19. The General Relationship between the Components of Reproductive Systems

\section{Conclusion}

Generative design as a dynamic tool, based on the rules governing complex natural systems, including evolution, self-organization and growth, enables the formation of complex formal and conceptual architectures through the implementation of a simple 
set of operations and parameters. By creating an idea of the designer as an algorithm, one can generate a code for each idea. By using a set of rules, the code-forming algorithm can be used to generate an architecture form in a self-organized process. In other words, the generative system is a productive system that does not specifically designate the product itself, instead, it specifies a higher level that encodes the "fabrication" of the product or method of design, and by this, and they mean that the form production set lower in level than the form itself. It suggested as fundamental shift from the modeling of a predesigned object to designing the logic of design. In this way, the design space is opened up to explore options and design variables, and promise to transfer some of the tasks and intelligences in the design by coding from person to person.

\section{References}

Alfonseca, M., and Ortega, A. (1997). A Study of the Representation of Fractal Curves by L Systems and Their Equivalences. IBM Journal of Research and Development, 41(6): 727-736. DOI: $10.1147 / \mathrm{rd} .416 .0727$

Bovill, C. (1996). Fractal geometry in architecture and design. Springer, Berlin. ISBN 978-1-4612-0843-3 DOI: 10.1007/978-1-4612-0843-3

El-khaldi, M. (2007). Mapping boundries of generative systems for design synthesis. Master of Science Thesis . Cambridge, Massachusetts, USA: MIT.

Flake, G. W. (1998). The Computational Beauty of Nature: Computer Explorations of Fractals, Chaos, Complex Systems, and Adaptation. Cambridge: The MIT Press. 229-258.

Flake, Gary William. (2000). The Computational Beauty of Nature: Computer Explorations of Fractals. Chaos. Complex Systems And Adaptation. Cambridge: The MIT Press. 103-106.

Frazer, J. (1995). An evolutionary architecture. London: Architectural Association Publications.

Frazer, J. H., Frazer, J. M., Liu, X., Tang, M. X. \& Janssen, P. (2002). Generative and evolutionary techniques for building envelope design. 5th International GenerativeArt. In: Generative Art 2002: 5th International Generative Art Conference GA2002, 11-13 December 2002, Italy, Milan.

Frenay, R. (2008). Pulse: The coming age of systems and machines inspired by living things. Lincoln: University of Nebraska Press.

Gursel, İ. D. (2012). Creative Design Exploration By Parametric Generative Systems In Architecture. Middle East Technical University Journal of the Faculty of Architecture , 29: 207-224. DOI: 10.4305/METU.JFA.2012.1.12

Hensel, M. (2014). Performance-oriented architecture: rethinking architectural design and the built environment. John Wiley \& Sons.

Hensel, M. \& Menges, A. (2008). Versatility and Vicissitude: An Introduction to Performance in Morpho-Ecological Design. Architectural Design, 78(2), 6-11.

Hensel, M., Menges, A., \& Weinstock, M. (2004). Emergence: Morphogenetic

Design Strategies. London: Academy Press

Hensel, M., Menges, A., \& Weinstock, M. (2010). Emergent technologies and design: towards a biological paradigm for architecture. London: Routledge.

Hensel, M., Menges, A. \& Weinstock, M. (2013). Emergent technologies and design: towards a biological paradigm for architecture: Routledge.

Holland, J. H. (1992). Genetic Algorithms. Scientific American, 267, 66 - 72.

Iwamoto, L. (2009). Digital fabrications: architectural and material techniques. Princeton Architectural Press.

Kaboli, M.H., Khandan, E. (2015). 101 Propositions for Biomimicry in Architecture. Tehran: Avalo Akhar Publishing.

Khabazi, Z. (2016). Digital Diposition of Materials., Kasra Publishing, Mashhad.

Lindenmayer, A., \& Prusinkiewicz, P. (1990). The Algorithmic Beauty of Plants. New York: Springer-Verlag.

Oxman, R. (2006). Theory and Design in The First Digital Age. Design Studies, 229-265. 
Oxman, N. (2012). Towards a material ecology. In 32nd Annual Conference of the Association for Computer Aided Design in Architecture (ACADIA), San Francisco.

Prusinkiewicz, P. (1986). Applications of L-systems to computer imagery. Paper presented at the International Workshop on Graph Grammars and Their Application to Computer Science.

Qaruni Esfahani, F. (2015). Bionic Architecture Designed By Nature. TehranUniversity publication, Tehran.

Rosenman, M., \& Gero, J. (1999). Evolving designs by generating useful complex gene structures. Evolutionary design by computers, 345-364.

Soddu, C., \& Colabella, E. (1995). Recreating The City's Identity with A Morphogenetic Urban Design. Making the Cities Livable. Freiburg: Freiburg-im-Breisgau.

Steadman, P. (2008). The Evolution of Designs: Biological analogy in architecture and the applied arts. Routledge.

Taraz, Masoumeh. (2012). Bionic Architecture (bio-industry), Design of Science and Technology Park. M.A Thesis. Tehran: Tehran University, Pardis Fine Art, Architecture Faculty.

Winston, Patrick H. (1992). Artificial Intelligence. 3rd editin. Addison Westly Publishing, New york.

Wolfram, Stephen. (1983). Statistical Mechanics of Cellular Automata, Rev. Mod. Phys. 55: 601. 